\title{
GENTIL MENDONÇA E O PIONEIRISMO NA REFUTAÇÃO DO SUPOSTO DIREITO POTESTATIVO DE DESPEDIR EMPREGADOS
}

\author{
Hugo Cavalcanti Melo Filho* \\ Everaldo Gaspar Lopes de Andrade**
}

\begin{abstract}
RESUMO
A notável produção do professor Gentil Mendonça não mereceu um tratamento acadêmico à altura da sua profundidade teórica. Por isso, precisa ser revisitada, no momento em que o ultraliberalismo global tenta um retorno às relações privadas clássicas, em que também se experimenta o desmonte e a desconstitucionalização dos direitos sociais. Neste trabalho se examina a teoria apresentada por Gentil Mendonça no texto intitulado "Realidade Jurídica do Direito de Despedir", no qual o autor apresente vigorosa rejeição a um direito absoluto de dispensar empregados, inclusive sem justa causa, fundada nas teorias do abuso de direito e do risco. O texto evidencia que, embora se reconheça ao empregador o direito de denunciar o contrato de trabalho, este direito está limitado pelas hipóteses legalmente indicadas, cuja desconsideração representará incontestável abuso de direito, a ensejar a necessária reparação, na forma de indenização, fundamentada na teoria do risco. $\mathrm{O}$ abuso de direito que a dispensa injusta representa não pode ser admitido pela ordem jurídica como um pretenso direito, mesmo que a ele se contraponha o dever de indenizar, porque isso não se equipara à perda do emprego, que se trata de direito vital.
\end{abstract}

Palavras-chave: direito; potestativo; abuso; ilícito; risco; indenização

\section{ABSTRACT}

Professor Gentil Mendonça's remarkable production hasn't deserved academic consideration compatible with its theoretical depth. For this reason, it needs to be revisited, in a moment when global ultraliberalism seeks to go back to classical private relationships, in which destruction and deconstitutionalization of social rights take place. This work examines the theory Gentil Mendonça presented in his article "Legal reality of the right to fire", in which he strongly rejects an absolute right to fire employees, even without proper cause, based on abuse of power and risk theories. His article shows that, although employers have the right to terminate the employment contract, some legal clauses limit that right, whose infringement would represent indisputable abuse of power and would generate a right to compensation, based on risk theory. The abuse of power which unjust firing represents cannot be accepted by the legal system as a right, even if it corresponds to a duty to compensate, because the latter is not comparable to the loss of employment, which is a vital right.

Keywords: Law; at will clause; abuse; illicit; risk; compensation.

\section{INTRODUÇÃO}

Professores da Faculdade de Direito do Recife produziram textos envolvendo as relações de trabalho desde o século XIX. Tobias Barreto foi redator, junto com José Higino Duarte Pereira,

\footnotetext{
* Professor da Faculdade de Direito do Recife. Mestre e Doutor em Ciência Política pela Universidade Federal de Pernambuco. Presidente da Academia Pernambucana de Direito do Trabalho.

*** Professor da Faculdade de Direito do Recife. Doutor em Direito pela Universidade de Deusto, Espanha. Membro da Academia Pernambucana de Direito do Trabalho.
} 


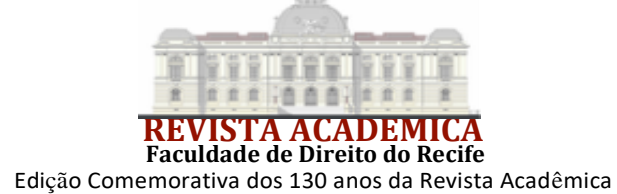

de uma revista intitulada $O$ Industrial, que circulou entre janeiro e dezembro de $1883^{1}$,

Tratando de uma economia subordinada a um regime antigo, escravocrata, a plataforma de $\mathrm{O}$ Industrial, a favor da mecanização da agricultura e do desenvolvimento industrial amplo, se constitui no sinal de modernização, organização econômica com liberdade [...] Atualizar as forças de trabalho com os últimos progressos da ciência e da técnica, nos domínios superiores da atividade industrial. (BARRETO, 1991, p. 185).

No início do século XX, essa produção se intensifica, sobretudo pelos estudos desenvolvidos pelo professor Joaquim Pimenta, ${ }^{2}$ na chamada fase considerada pré-científica do Direito do Trabalho. Uma fase imprescindível para a compreensão do próprio surgimento da disciplina Direito do Trabalho nessa mesma faculdade.

Nas décadas seguintes, é preciso destacar a presença do professor Gentil Mendonça na formação dessa disciplina, na medida em que integrou o elenco dos primeiros juslaboralistas brasileiros, embora não tenha recebido o mesmo destaque, quando se busca comparar as referências, que indicam, prioritariamente, professores que atuaram nas faculdades de Direito do Sul do país.

Pesquisa bibliográfica conduz à descoberta de um conjunto extraordinário de textos e livros que se apresentam no mesmo patamar de importância, quando comparados à produção acadêmica forjada noutras faculdades, também pioneiras na construção dessa disciplina, especialmente na Região Sudeste do Brasil.

O professor Gentil de Carvalho Mendonça nasceu na cidade de Maceió, no dia 12 de março de 1911. Estudou e formou-se na Faculdade de Direito do Recife, em 1936. Já na década seguinte, disputava cátedras naquela faculdade e vivia o ambiente político e social da sua época. Nos anos 1940 vieram a lume a tese escrita para obtenção da Livre Docência de Teoria Geral do Estado ${ }^{3}$ e a tese para aprovação à Cátedra de Direito Internacional Público ${ }^{4}$ daquele mesma faculdade.

Não demorou até que ele apresentasse à comunidade acadêmica uma série de livros sobre Direito do Trabalho, que se notabilizaram pelos conteúdos, envolvidos simultaneamente com História, Ciência Política e Social, Economia, Filosofia e que legaram àqueles que passaram a ter contato com essa nova disciplina jurídica uma visão consistente do ponto de vista teórico, sem deixar de lado as análises dogmáticas, especialmente no que se referia ao subsistema jurídicotrabalhista brasileiro. A obra de estreia nesta seara foi Evolução das Leis Obreiras e o Novo Conceito do Trabalho, de 1946, seguida por Evolução Geral do Trabalho, publicada em 1950, e, no mesmo ano, Autonomia do Direito do Trabalho, tese apresentada para a obtenção da Livre Docência de Direito Industrial e do Trabalho da Faculdade de Direito do Recife.

A notável produção do professor Gentil Mendonça se consolida e se expande nas décadas de 1960 e 1970, com destaque para os livros Estudos de Direito do Trabalho (1962), Curso de Direito do Trabalho (1965), Curso de Direito do Trabalho (1967), Curso de Direito do Trabalho, Vol. III (1972) e A Interpretação do Direito do Trabalho (1978).

Embora tenha sido contemporânea de tantos outros juslaboralistas que fizeram história noutras faculdades, a obra de Gentil Mendonça não mereceu um tratamento acadêmico à altura da sua profundidade teórica. Por isso, precisa ser revisitada, no momento em que o ultraliberalismo global tenta um retorno às relações privadas clássicas, em que também se experimenta o desmonte e a desconstitucionalização dos chamados direitos sociais.

Nesse propósito, o Grupo de Pesquisa Direito do Trabalho e Teoria Social Crítica

\footnotetext{
${ }^{1}$ BARRETO, Tobias; MERCADANTE, Paul; PAIN, Antônio; BARRETO, Luiz Antônio (org.). Estudos Alemães. Rio de Janeiro: Recorde, 1991.

2 PIMENTA, Joaquim. Ensaios de Sociologia e Direito. Recife: Imprensa Industrial, 1915. Texto escrito para concorrer à Livre Docência da cadeira Philosophia Jurídica na Faculdade de Direito do Recife.

${ }^{3}$ MENDONÇA, Gentil de Carvalho. Considerações sobre o homem e o estado totalitário. Recife: texto avulso, 1940. 4 MENDONÇA, Gentil de Carvalho. O Estado Internacional. Recife: texto avulso, 1943.
} 


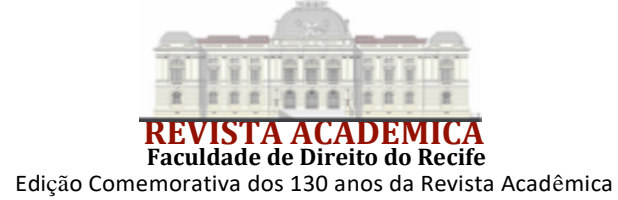

apresentou à aprovação pelo Programa de Pós-graduação em Direito da Universidade Federal de Pernambuco o Projeto de Pesquisa No rastro da história do Direito Brasileiro do Trabalho: Gentil de Carvalho Mendonça e a primeira cátedra desse campo da ciência jurídica na Faculdade de Direito do Recife.

O projeto pretende não apenas restaurar essa rica bibliografia, para que ela fique permanentemente disponibilizada, mas, especialmente, promover um debate contemporâneo e publicações sobre a obra de Gentil Mendonça, seguindo a trilha da evolução do próprio Direito do Trabalho.

Este texto é o primeiro produto do projeto mencionado. Aqui se examina a teoria apresentada por Gentil Mendonça, no livro A Interpretação do Direito do Trabalho, publicado pela Editora LTr, em 1978, sobre a natureza do ato jurídico de dispensa do empregado, no inovador capítulo "Realidade Jurídica do Direito de Despedir".

A exemplo do que fizera ao publicar, na Revista Acadêmica da Faculdade de Direito do Recife, o artigo Higiene e Segurança do Trabalho, ainda em 1962, antecipando debate sobre o referido tema, Gentil Mendonça, no texto aqui analisado, na esteira de José Martins Catharino (Em defesa da estabilidade: despedida versus estabilidade, 1965) e de Evaristo de Moraes Filho (A justa causa na rescisão do contrato de trabalho, 1966), revelou pioneirismo na discussão sobre o suposto direito potestativo de despedir, reconhecido por certa doutrina - que se mantém majoritária até hoje -, posicionando-se firmemente contra tal concepção e aportando argumentos jurídicos os mais avançados em desfavor dela.

O tema seria retomado, no âmbito do PPGD/UFPE, pelo Professor Sergio Torres Teixeira, que publicou sua pesquisa, em 1998, sob o título Proteção à Relação de Emprego, seguido por diversos autores, como Leonardo Wandelli (Despedida abusiva: o direito (do trabalho) em busca de uma nova racionalidade, 2004), Arion Sayão Romita (Proscrição da Despedida Arbitrária, 2011) e, mais recentemente, por Valdete Souto Severo (A perda do emprego no Brasil, 2021) e Jorge Luís Souto Maior (Dispensa coletiva não é um direito, 2021), publicações que revelam a absoluta atualidade da discussão.

\section{REALIDADE JURÍDICA DO DIREITO DE DESPEDIR}

No artigo científico publicado sob o título em epígrafe, Mendonça parte do argumento de que a progressão técnica, o avanço científico, promoveram significativas mudanças no campo do Direito, especialmente no Direito de Propriedade, em permanente transformação, no sentido da diluição do privatismo, da mitigação da liberdade de que antes desfrutavam os proprietários sobre as respectivas propriedades. Isso como resultado da renovação no campo da contratualística, com a prevalência dos interesses sociais sobre os interesses individuais.

No âmbito do Direito do Trabalho, tais transformações conduziram o empregado ao centro dessa dinâmica revolucionário-científica, influenciando de forma decisiva os contornos dessa disciplina jurídica, nomeadamente com a eliminação de "conceitos primitivos de propriedade absoluta". O autor não nega o direito de propriedade resultante da iniciativa privada, mas ressalta as limitações impostas pela evolução científica a este mesmo direito. E, delineado o contexto, suscita a questão: o empregador proprietário tem o direito de despedir seu empregado sem a ocorrência de uma causa justa? Sob qual fundamento?

Para responder a questão, Gentil Mendonça se vale de diversas teorias: teoria do abuso de direito; teoria do risco profissional ou social; teoria do crédito; teoria do dano; teoria do salário diferido; teoria do prêmio; teoria da pena; teoria previdencial. Com esteio nas duas primeiras abuso de direito e risco - refuta as teses que sustentam o direito-poder de despedir, para, depois, desmontar todas as demais teorias, com base nas quais foram erigidas as teses do direito potestativo de dispensa de empregados. 


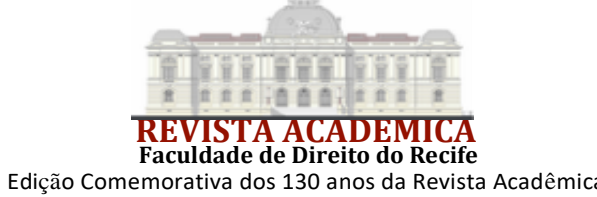

\subsection{TEORIA DO ABUSO DE DIREITO}

O autor não nega a possibilidade de o empregador despedir empregados, desde que haja um justo motivo. Sustenta que se, de um lado, o emprego não é propriedade do empregado, de outro, não é propriedade do empregador, ao menos em termos absolutos. Esgrime, em benefício do argumento, a imposição legal de indenizar o empregado injustamente despedido que, em sua visão, decorre do abuso de direito praticado pelo empresário que despede em tais circunstâncias.

Importante registrar que o texto foi produzido em 1978, portanto dez anos antes de a Constituição de 1988 assegurar, no inciso I do artigo 7. ${ }^{\circ}$, a garantia contra dispensa arbitrária ou injusta, prescrevendo, inclusive, direito a indenização compensatória. À época, o autor fundamentava o argumento nos artigos 477, 482, 497, 498, da CLT.

Em outras palavras, Gentil Mendonça advoga que o empregador não dispõe absolutamente dos empregos que gera, de modo que se lhe admite a dispensa motivada de empregados, mas não a dispensa sem causa justa que, a rigor, representa abuso de direito empresarial.

Isto porque, a profunda relação social entre o empregado e o emprego não pode admitir como prerrogativa do empresário o direito absoluto de despedir, mesmo o trabalhador não estável ${ }^{5}$. A empresa, sustenta o autor, não é mais a propriedade completa daqueles que detêm os seus capitais ou as dirige, do que decorre o abuso de direito social na hipótese de dispensa sem justa causa.

O professor rechaça o argumento segundo o qual o fato de a empresa assumir o risco da atividade econômica justifica um direito potestativo de despedir. E arremata: "Se a lei estabelece sanções, houve ilícito. E se o ilícito existe, não existe o direito potestativo de cometer o próprio ilícito". (MENDONÇA, 1978, p. 77).

O direito ao trabalho, assegurado em todo o mundo, atribui centralidade ao emprego, no Direito do Trabalho. A concepção de que a indenização se assemelha ou corresponde ao emprego, e a suposta prerrogativa decorrente de tal correspondência de o empregador definir pela manutenção no emprego ou pela dispensa, mediante indenização, nega a própria teleologia do Direito do Trabalho que, em última análise, é a permanência do trabalhador no emprego. "Pretender arrazoar esse direito de despedir, uma vez que o empregador paga a indenização determinada em lei, é raciocinar pelo fim, pelas consequências e não pelo princípio, isto é, pelo ato de despedir" (ibidem, p. 77).

Não é razoável admitir, segundo o autor, falar-se em direito de cujo exercício decorra o dever de indenizar. Ao elencar as hipóteses de dispensa justa, no art. 482 da CLT, o legislador, taxativamente, limitou as possibilidades do empregador de por fim ao contrato de trabalho àquele rol. Implicitamente está declarado que a relação de emprego há de continuar, salvo o cometimento de uma daquelas faltas. Se o empregador despede fora de tais parâmetros, comete abuso de direito e estará obrigado a indenizar. Nada mais distante, portanto, de um direito potestativo.

"Há uma copropriedade social [do emprego], se se pretende dar uma função verdadeira à empresa que é um complexo material e humano" (ibidem, p. 78). A empresa, assim, não é proprietária dos empregos. Por isso, só se justifica a despedida de empregados "com a justa causa objetivamente ostensiva" (ibidem, p. 78). Outorgar ao empregador o direito absoluto de despedir corresponde a sufragar "o direito de se cometer o ilícito de maneira premeditada, refletida e esquematizada", um direito que tem "o seu uso preconcebido no abuso de direito" (ibidem, p. 78).

Em suma, se existe um poder de fato de despedir, a ele não corresponde um poder de direito. "A passagem do fato à norma", afirma o autor, "não é tão fácil, pois esta exige uma decantação de valores, um joeirar de circunstâncias, colhendo-se o que há de ético e justo e cujo fim seja o bem comum" (ibidem, p. 78). Daí porque o direito dispõe em sentido diametralmente oposto: obriga o empregador a provar o cometimento de falta do empregado decenalmente estável, sob pena de ter

5 À época da publicação da obra, o regime da estabilidade decenal convivia com o do Fundo de Garantia do Tempo de Serviço, muito embora, já ali, a maioria dos trabalhadores fossem optantes por este último. 


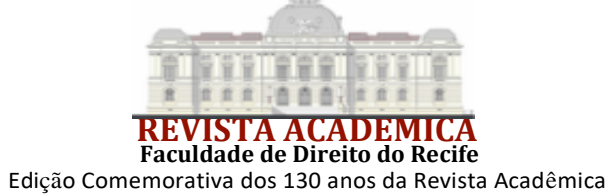

que reintegrá-lo e pagar-lhe os salário vencidos durante o afastamento; atribui à Justiça do Trabalho a prerrogativa de converter o direito à reintegração em indenização que, neste caso, será em dobro.

Gentil Mendonça afirma que "não é possível aceitar-se hoje mais esse autoritarismo exclusivo e excludente, numa época de profundas transformações humanas e sociais" (ibidem, p. 78). Por isso mesmo, quando o empregador deixa de observar o objetivo declarado do Direito do Trabalho, a permanência do empregado no emprego, "ocasiona a aludida indenização, como uma reparação" (ibidem, p. 80).

Toda a apreciação, à luz da teoria do abuso de direito, é feita a partir do suposto direito de despedir, o que leva o autor, na esteira de Aníbal Freire, a estabelecer um diálogo entre aquela teoria e a teoria do risco. $\mathrm{O}$ autor desenvolve uma sofisticada relação entre as duas teorias para, partindo do abuso do direito social (representado pela dispensa injusta) como ilícito social, chegar à responsabilidade objetiva do empregador, dada a amplitude social e econômica do Direito do Trabalho.

\subsection{TEORIA DO RISCO PROFISSIONAL OU SOCIAL}

Gentil Mendonça considera que resta configurada a responsabilidade objetiva no ato de despedir. A culpa objetiva, segundo o autor, "é a do complexo social, da marcha dinâmica da sociedade industrial, dos lucros auferidos, do aproveitamento do trabalho de outrem para o engrandecimento do patrimônio privado" (ibidem, p. 81).

Assim,

A determinação de despedir sem justa causa partiria do abuso de direito e terminaria no abuso de direito social, decorrendo daí a responsabilidade objetiva de indenização, posto que no Direito do Trabalho é predominantemente social e com fins econômicos, fazendo até lembrar Saleilles, que diz configurado o ato abusivo desde quando haja distorção de seus fins sociais e econômicos. É um critério finalista e de resultado. (ibidem, p. 81).

O autor confronta a opinião de "certos juristas" contrária à concepção de aplicabilidade da teoria do risco à dispensa injusta, opinião construída a partir da idéia de que o empregador detêm o direito potestativo de romper o liame empregatício, que estaria compreendido em um processo de compensação pelo risco que corre, em contraste com a posição do empregado, que não participa dos eventuais prejuízos da empresa.

Mas o direito potestativo só existe quando o seu detentor "o desfruta mansa e pacificamente em toda a sua plenitude, sem restrições ou reservas" (ibidem, p. 82), o que não se compatibiliza, em absoluto, com limitações ao "direito de despedir" dadas pela intervenção legal na dispensa sem justa causa.

Em contraste com as teorias que preconizam o predomínio da subjetividade na configuração do ato ilícito, que presume a ocorrência de dolo ou culpa, o autor defende que o ato ilícito - que se constitui em abuso de autoridade - de despedir empregado sem justa causa, situada na esfera do Direito do Trabalho, um direito social, não pode deixar de ser compreendido na perspectiva da responsabilidade social ou objetiva, ou finalística, como preconiza Saleilles: "a despedida sem justa causa é um abuso de direito e, por isso, um ilícito trabalhista. Não nos interessam as origens subjetivas dessas manifestações". (ibidem, p. 82)

Gentil Mendonça, citando Souza Neto, afirma que "há no sistema de nossa lei um verdadeiro direito ao emprego (...) e a razão de prevalecer neste caso o interesse do empregado é que ele coincide perfeitamente com o da coletividade" (ibidem, p. 83). Então, considerando que o Direito do Trabalho visa, precipuamente, à coletividade, e que adota a teoria do risco profissional ou social em temas como acidente de trabalho (responsabilidade objetiva), que atribui ao empregador o ônus da provar a falta do empregado como pressuposto da dispensa por justa causa 


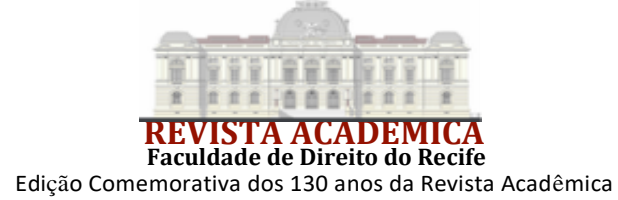

(teoria objetiva), é juridicamente compatível a reunião do "ato ilícito (abuso de direito) com a teoria de do risco profissional ou social" (ibidem, p. 83).

Segundo o autor, na dispensa do empregado "há uma previsão de desemprego e é a empresa responsável por esse desemprego. Não há outro caminho senão indenizar o empregado, atendendo não somente à sua pessoa, porém aos interesses sociais ou coletivos" (ibidem, p. 83). O mais modesto empregador sabe, ao despedir um empregado sem motivo, que está cometendo um ato ilícito, que sua deliberação é ilegal e sujeita à reparação.

Nesse ponto, Mendonça adverte para o problema de se adotar uma teoria exclusiva para explicar o problema da despedida no Direito do Trabalho. Por exemplo, a adoção da teoria do risco social, unicamente, conduziria à explicação da indenização decorrente da dispensa injusta pelo modo pelo qual dever ser encarada, pelas consequências e não pelas causas. Mas tal consideração careceria de uma explicação para a origem de tal procedimento, para além do resultado, atraindo a aplicação da teoria do abuso de direito social.

Assim, para "satisfazer a curiosidade científico-jurídica do estudioso", afirma o autor, "o melhor caminho mesmo é admitir que a teoria do abuso de direito está em união com a teoria do risco" (ibidem, p. 83), para explicar o despedimento injusto do empregado, ainda que haja hipóteses em que mesmo o abuso de direito não estando presente, assume o empregador o dever de indenizar pela terminação do contrato exclusivamente em virtude do risco.

Com efeito, na despedida injusta (art. 477, CLT), na despedida indireta (art. 483, CLT) e na despedida obstativa de aquisição da estabilidade (art. 499, § 3. ${ }^{\circ}$, CLT), está presente o abuso de direito. Mas nos casos de extinção da empresa (art. 497, CLT), inclusive em virtude de força maior (art. 502, CLT), não há falar em abuso de direito do empregador (responsabilidade subjetiva), senão, exclusivamente, em teoria do risco (responsabilidade objetiva) a fundamentar o dever de indenizar. "O que predomina, em todas essas circunstâncias é o direito sagrado à indenização" (ibidem, p. 84).

\section{TEORIAS QUE FUNDAMENTAM O SUPOSTO DIREITO POTESTATIVO DE DESPEDIR}

No texto em comento, o autor refuta as teorias que dão supedâneo à tese do direito potestativo de despedir, por elas reconhecida ao empregador. Em todas elas, o direito que se reconhece ao trabalhador de ser indenizado pela dispensa não decorre do abuso direito do empregador - que não é por elas reconhecido - ou do risco. Segundo a teoria do crédito, o direito à indenização decorre de um crédito constituído pelo empregado sobre os fundos do estabelecimento, pela colaboração que trouxe à prosperidade desta, no tempo em que exerceu suas funções na empresa. Tal crédito, segundo a teoria, não se trata de salário, até porque, se salário fosse, não seria admitida a retenção até o momento do desenlace contratual. Mas se se trata de "um direito previamente adquirido e cujo fundamento é o desempenho no seu trabalho, com aceitação por parte do empregador" (ibidem, p. 85), o que justificaria o não pagamento do crédito no caso do cometimento de uma falta grave ou pedido de demissão?

Por seu turno, a teoria do dano "tem o objetivo de equiparar [a indenização] a uma compensação em relação ao emprego perdido" (ibidem, p. 86), partindo do resultado, o dano, sem questionar o motivo dele. O dano estaria configurado no ato de despedir. Gentil Mendonça questiona a teoria, a partir do argumento de que o reemprego, por exemplo, não configura dano, para alguns doutrinadores, entretanto, ainda assim, não desfigura a responsabilidade pela indenização do empregador despedido e, depois, recontratado ${ }^{6}$.

A teoria do salário diferido, rechaçada por completo pelo autor, informa que o empregado, ao ser despedido, recebe, na verdade, parte do salário retido pelo empregador no curso do contrato

${ }^{6} \mathrm{O}$ argumento é utilizado apenas para apontar a possível fragilidade da teoria, uma vez que, em seguida, o autor admite considerar que, mesmo no caso de reemprego, houve uma perturbação do empregado, que já configura dano. 


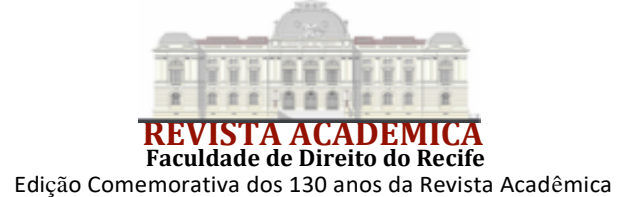

de trabalho. A ideia é a de que o empregado recebe um salário menor do que o que lhe é devido, que somente é complementado no momento da dispensa. Esta teoria nega, portanto, a natureza indenizatória do valor recebido em decorrência da terminação injusta do contrato, que, a rigor, já integraria o patrimônio jurídico do trabalhador, apenas pendente de entrega pelo patrão. Com o pagamento de tal salário diferido, então, o empregador ficaria livre de qualquer dever de indenizar pela dispensa injusta. $\mathrm{O}$ autor reputa a teoria absolutamente ilógica, além de justificar "a injustiça como critério indicado para pagar menos do que lhe era devido" (ibidem, p. 87).

Há autores, segundo Gentil Mendonça, que explicam a indenização como "um prêmio de fidelidade ou benemerência" (ibidem, p. 87). Em outras palavras, o comportamento do empregado durante o desenvolvimento do liame empregatício, sua conduta no cumprimento de seus dever como empregado, o mérito, portanto, definiria o direito de receber tal prêmio, no momento da dispensa pelo empregador, independentemente do tempo que esteve prestando serviços à empresa. Aí está a teoria prêmio, questionada pelo autor, primeiro quanto à possibilidade de perda do prêmio, por ausência de mérito, mesmo na hipótese de antiguidade na empresa, depois quanto aos critérios para o reconhecimento de tal mérito, condicionado à colaboração dada à mesma empresa ${ }^{7}$.

A teoria da pena equipara a indenização a uma sanção aplicada ao empregador pela despedida injustificada do empregado. Aqui, o autor cita Mozart Victor Russomano, para afirmar que "a teoria da pena confunde a pena, punição imposta, com o simples ato civil de cumprimento de obrigação, ou, ao menos, de ressarcimento de dano causado" (ibidem, p. 88). Para ele, tal teoria não explica os fundamentos jurídicos que determinam a indenização, uma vez que, segundo ela,

\begin{abstract}
se há o pagamento da indenização, nada há mais a argumentar, porque esta supriu o emprego, não havendo, portanto, qualquer restrição àquele poder absoluto de despedir. Desaparecem, assim, as razões morais e profissionais do emprego, que se transforma em mercadoria. Foi vendido, aliás, foi comprado por dinheiro, sem qualquer outra indagação. (ibidem, p. 88).
\end{abstract}

Por outro lado, a teoria admite uma compreensão negativa, ou seja, a afirmação da inexistência dessa pena, como critério para explicar o fundamento jurídico da indenização, com o argumento de que o empregador tem o direito absoluto de despedir, com ou sem justa causa, e, assim, não pode sofrer pena pelo exercício de tal direito.

$\mathrm{O}$ autor reitera que a indenização "resulta do abuso de direito, marchando em determinadas hipóteses para a responsabilidade social ou risco social, ou simplesmente, risco, mas, sempre, responsabilidade" (ibidem, p. 88).

Por fim, Gentil Mendonça menciona, brevemente, a teoria previdencial, para rejeitá-la também, ao argumento de que não se pode admitir a dependência da indenização do empregado despedido ao Direito Previdencial, uma vez que "a Previdência está toda voltada para o futuro do trabalhador, enquanto a indenização como prestação previdenciária (...) tem em vista o passado do empregado"8 (ibidem, p. 89).

\title{
4 DIREITO POTESTATIVO E FUNÇÃO SOCIAL DO EMPREGO
}

Obtempera o autor que atribuir ao empregador o poder de despedir sem justa causa é reconhecer-lhe um direito potestativo em face dos empregados. Entretanto, tal reconhecimento importaria contrariedade às disposições contidas no art. 482 da ClT, entre outros dispositivos

\footnotetext{
${ }^{7}$ Embora o autor não o tenha mencionado, esta teoria não tem o condão de explicar o pagamento de indenização ao empregado nos casos de dispensa injusta, de encerramento da empresa, de força maior, que independe do desempenho do trabalhador no curso do contrato. Quando muito, abarcaria as hipóteses de justa causa, nas quais a falta grave cometida pelo empregado retiraria o mérito eventualmente reconhecido.
}

${ }^{8}$ Aqui, o autor cita Otávio Bueno Magano. 


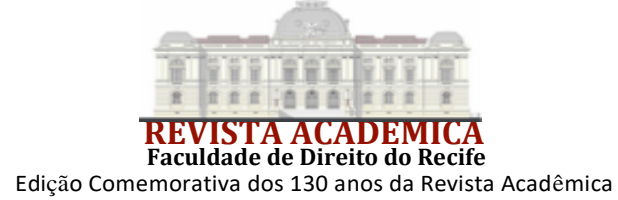

legais, que limitam as possibilidades de dispensa às hipóteses neles contidas.

Haveria aí uma contradição insuperável, pois não é possível se sustentar um direito potestativo de despedir contrário aos limites estabelecidos em lei à dispensa, "pois tudo que está fora do alcance dos dispositivos da própria lei não constitui justa causa para, repitamos, despedir" ((ibidem, p. 90). Em reforço a tal argumento, o autor aponta a situação do empregado estável, que não pode ser alcançado pela decisão empresarial de despedir, de modo que não se pode falar em direito potestativo.

Mesmo em relação aos empregados não estáveis e, dentre eles, aos optantes pelo regime do Fundo de Garantia do Tempo de Serviço, haveria limitação ao direito de despedir sem justa causa, consubstanciada no dever de indenizar, quanto aos primeiro, e na obrigação de pagamento de multa sobre os depósitos havidos na conta vinculada - e, antes disso, de "contribuir mensalmente (...), amparando o empregado de uma possível despedida" (ibidem, p. 92) - quanto aos últimos. $\mathrm{O}$ autor afirma considerar a referida multa uma forma indenizatória. Assim, em ambos os casos, não seria possível falar em direito potestativo, quando a legislação aplica corretivos à despedida injusta, "o próprio Estado intervém, procurando amenizar os efeitos desse poder de despedir" (ibidem, p. 90). "A despedida é tão anti-social que o Estado regulamentou tal procedimento através de uma compensação financeira" (ibidem, p. 91).

Isto porque,

É o Direito do Trabalho um direito solidarista, dando clara margem de interpretação no sentido de o Estado considerar normal o emprego. (...) A chamada 'declaração unilateral de vontade' vai de encontro a um contrato bilateral que somente pode ser rompido por parte do empregador de maneira direita, segundo os critérios do art. 482, e indireta, nos termos indicados no art. 483. (ibidem, p. 92).

Gentil Mendonça afirma que a continuidade do emprego é um pressuposto do contrato de trabalho. "O objetivo do Direito do Trabalho é a permanência do empregado no emprego, como uma das razões da paz social" (ibidem, p. 93). Tanto assim que o art. 10 da CLT assegura os direitos adquiridos pelo empregado na hipótese de alteração na estrutura jurídica da empresa, de modo que o contrato se mantém, garantidos tais direitos. Não é possível compatibilizar direitos adquiridos do empregado com um direito potestativo do empregador de o despedir.

A lei não pode aceitar um comportamento anormal [a despedida fora das hipóteses do art. 482 da CLT], como um pretenso direito, seja lá de quem for. Quer dizer que a despedida sem justa causa não é o que a lei deseja nem espera. Essa reparação do emprego perdido é muito relativa, pois esse não se recupera, sobretudo em se tratando de um direito vital. Aceitar-se uma equivalência entre uma realidade e outra é diminuir o valor econômico e moral do emprego, enquanto, por outro lado, é comprar o abuso de direito por um preço muito barato. (ibidem, p. 95).

O autor cita La Gressaye, Rouast, Durand e, especialmente, Gerorges Ripert, todos defensores da tese de que os empregados são proprietários dos respectivos empregos, para deles discordar. Afirma que não reconhece uma propriedade individual do emprego, seja do empregador, seja do empregado, e sim uma propriedade social. Daí porque não aceita o direito potestativo de despedir sem justa causa, como privilégio do empregador, "o que vai de encontro à harmonia social, ao conceito moderno de empresa e à visão institucional desta" (ibidem, p. 96).

Gentil Mendonça conclui o texto com uma profissão de fé no Direito do Trabalho, "um direito novo, com suas singularidades e seus aspectos surpreendentes, inclusivamente, em certos momentos, contrários às disposições do direito comum" (ibidem, p. 100). Um direito "que não é mais prisioneiro de um contrato, no qual a vontade do mais forte se sobrepõe à vontade do mais fraco" (ibidem, p. 100), sendo que "uma de suas particulares grandezas [é] a de humanizar cada 


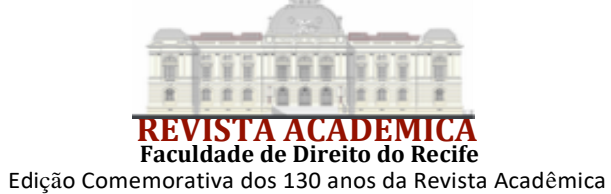

vez mais a coletividade, e, consequentemente, o próprio indivíduo, invadindo o Estado certas demarcações que ontem seriam consideradas utópicas na sua penetração" (ibidem, p. 101). Um direito "que se agiganta, que vai à frente com as realidades, com a maior sensibilidade e espírito de solidariedade. E que vai ao encontro dos interesses da própria sociedade" (ibidem, p. 101).

E arremata:

Em uma época onde se verifica tal renovação de valores ou mesmo de inovação, não se pode aceitar aquele poder decisório absoluto de despedida do emprego, posto que este é o maior alicerce do Direito do Trabalho, pois é o mesmo emprego de onde derivam essas modificações e esse alto espírito de compreensão social. (ibidem, p. 101).

\section{CONSIDERAÇÕES FINAIS}

O texto do Professor Gentil Mendonça aqui analisado revela-se, acima de tudo, contrahegemônico. No momento em que foi escrito e publicado, no final da década de 1970, a doutrina na seara jurídico-trabalhista se curvava, quase integralmente, à tese do direito potestativo de o empregador despedir seus empregados, por ser considerado proprietário dos empregos que gerava.

É de notar, também, que a obra examinada pode ser considerada como precursora da teoria crítica do Direito do Trabalho, que seria desenvolvida nas décadas seguintes, pois não se limita a criticar teoricamente o direito instituído, senão avança no sentido do resgate da dimensão política do direito, para o atendimento das demandas dos trabalhadores e garantia da dignidade da pessoa humana.

A vigorosa rejeição de um direito absoluto de dispensar empregados, inclusive sem justa causa, fundada nas teorias do abuso de direito e do risco, reveste tal prática empresarial da ilicitude que ela, a rigor, configura. $\mathrm{O}$ texto evidencia que, embora se reconheça ao empregador o direito de denunciar o contrato de trabalho, este direito está limitado pelas hipóteses legalmente indicadas, cuja desconsideração representará incontestável abuso de direito, a ensejar a necessária reparação, na forma de indenização, fundamentada na teoria do risco (responsabilidade objetiva).

Entretanto, a reparação, no caso de dispensa imotivada, não o satisfaz. O abuso de direito que a dispensa injusta representa não pode ser admitido pela ordem jurídica como um "comportamento normal", como um pretenso direito, mesmo que a ele se contraponha o dever de indenizar, porque isso não se equipara à perda do emprego, que se trata de direito vital. É assim que Gentil Mendonça rejeita a equivalência que se pretende estabelecer entre o emprego e a indenização pela perda dela, por abuso de direito do empregador, pois que "aceitar-se uma equivalência entre uma realidade e outra é diminuir o valor econômico e moral do emprego, enquanto, por outro lado, é comprar o abuso de direito por um preço muito barato".

Dez anos após a publicação de tão potente texto, a Constituição de 1988 trouxe em seu bojo a garantia do trabalhador brasileiro contra a dispensa arbitrária ou injusta. Entretanto, tal direito segue sendo sonegado, sob o argumento de que a norma constitucional demanda regulamentação, que jamais foi providenciada, passados 33 anos da promulgação da Carta.

Pior, a legislação ordinária desde então produzida, no sentido contrário ao que a Constituição pretendeu assegurar, vem ampliando as possibilidades de dispensa de empregados, inclusive de forma massiva, como a querer reforçar, insistentemente, a tese do direito potestativo do empregador de despedir. Estamos em momento de questionar, com Gentil Mendonça: "de que valem os princípios solidaristas do Direito do Trabalho? Como pode o empregador usar de um poder decisório contra a própria lei?" (ibidem, p. 96)

Mas a obra de Gentil Mendonça nos anima a acreditar que o Direito do Trabalho - que ele afirma um direito novo e surpreendente, que se agiganta e vai à frente, com sensibilidade e espírito de solidariedade, ao encontro dos interesses da própria sociedade - possa, em algum momento, assegurar "uma integração mais perfeita do empregado na empresa, [momento em que] esse direito potestativo passará a ser uma relíquia ou uma borboleta morta na coleção de seus caçadores" 
(ibidem, p. 82), como previsto no texto aqui analisado. A ver.

\section{REFERÊNCIAS}

BARRETO, Tobias; MERCADANTE, Paulo; PAIN; Antônio; BARRETO, Luiz Antônio (org.). Estudos Alemães. Rio de Janeiro: Recorde, 1991.

MENDONÇA, Gentil de Carvalho. Considerações sobre o homem e o estado totalitário. Recife: texto avulso, 1940.

MENDONÇA, Gentil de Carvalho. O Estado Internacional. Recife: texto avulso, 1943.

MENDONÇA, Gentil de Carvalho. Evolução Geral do Trabalho. Recife: Imprensa Oficial, 1950.

MENDONÇA, Gentil de Carvalho. Estudos de Direito do Trabalho. Recife: Imprensa Universitária 1962.

MENDONÇA, Gentil de Carvalho. Curso de Direito do Trabalho. Recife: Imprensa Universitária, 1965.

MENDONÇA, Gentil de Carvalho. Curso de Direito do Trabalho. Recife: Imprensa Universitária, 1967. v. 2.

MENDONÇA, Gentil de Carvalho. Curso de Direito do Trabalho. Recife: Editora Universitária, 1972. v. 3.

MENDONÇA, Gentil de Carvalho. A Interpretação do Direito do Trabalho. São Paulo: LTr, 1978.

PIMENTA, Joaquim. Ensaios de Sociologia e Direito. Recife: Imprensa Industrial, 1915. Texto escrito para concorrer à Livre Docência da cadeira Philosophia Jurídica na Faculdade de Direito do Recife. 